Article

\title{
A Field Study on Thermal Comfort in Multi-Storey Residential Buildings in the Karst Area of Guilin
}

\author{
Xinzhi Gong ${ }^{1,2, * \mathbb{D}}$, Qinglin Meng ${ }^{2}$ and Yilei Yu ${ }^{3}$ \\ 1 Guangxi Key Laboratory of New Energy and Building Energy Saving, College of Civil Engineering and \\ Architecture, Guilin University of Technology, Guilin 541004, China \\ 2 State Key Laboratory of Subtropical Building Science, South China University of Technology, \\ Guangzhou 510640, China; arqlmeng@scut.edu.cn \\ 3 The Design School, Herberger Institute for Design and the Arts, Arizona State University, Tempe, AZ 85281, USA \\ yileiyu@asu.edu \\ * Correspondence: gxinzhi@glut.edu.cn; Tel.: +86-173-0773-5290
}

Citation: Gong, X.; Meng, Q.; Yu, Y. A Field Study on Thermal Comfort in Multi-Storey Residential Buildings in the Karst Area of Guilin. Sustainability 2021, 13, 12764. https://doi.org/ $10.3390 /$ su132212764

Academic Editors: Chun-Qing Li,

Yaolin Lin and Wei Yang

Received: 30 August 2021

Accepted: 8 November 2021

Published: 18 November 2021

Publisher's Note: MDPI stays neutral with regard to jurisdictional claims in published maps and institutional affiliations.

Copyright: (c) 2021 by the authors. Licensee MDPI, Basel, Switzerland. This article is an open access article distributed under the terms and conditions of the Creative Commons Attribution (CC BY) license (https:/ / creativecommons.org/licenses/by/ $4.0 /)$.

\begin{abstract}
It is important to consider reducing energy use while improving occupants' indoor thermal comfort. The actual thermal comfort needs and demands should be considered to determine the indoor thermal environment design. In previous studies, research has not been carried out on thermal comfort in karst areas. Thus, a long-term field investigation was carried out on multi-storey residential buildings in the karst area of Guilin city centre during summer (from August 2019 to September 2019) and winter (from December 2019 to January 2020). In this study, the indoor thermal environments of three categories of dwellings were analysed. A total of 77 residential buildings with 144 households were randomly selected, and 223 occupants from 18 to 80 years old participated. A total of 414 effective questionnaires were collected from the subjects. The results show that there was an obvious conflict between the predicted mean vote (PMV) and the thermal sensation vote (TSV). The neutrality temperatures calculated by the regression method were $24.2^{\circ} \mathrm{C}$ in summer and $16.2{ }^{\circ} \mathrm{C}$ in winter. The thermal comfort range was observed at operative temperatures of $20.9-27.5^{\circ} \mathrm{C}$ in summer and $12.2-20.1{ }^{\circ} \mathrm{C}$ in winter. The desired thermal sensation for people in the Guilin karst area was not always reflected in the thermal neutrality range. A preference for warmness was identified in the survey.
\end{abstract}

Keywords: field study; thermal comfort; residential building; Guilin karst area

\section{Introduction}

Thermal comfort research has been a hot topic in recent years [1]. It is important to consider reducing energy use while improving occupants' indoor thermal comfort. Due to economic growth, there has been a continued and growing demand for the improvement of indoor thermal environments and, consequently, the growth of energy demand for both heating and cooling [2]. In residential buildings, varieties of thermal sensation and comfort requirements significantly impact energy consumption [3]. There would be a potential waste of energy to maintain the indoor thermal comfort thresholds using the thermal comfort standards directly [4] because of the different thermal comfort characteristics in different outdoor climates and areas [5]. The indoor thermal environment should be carefully analysed and controlled with consideration for the actual thermal comfort threshold needs and requirements.

Thermal comfort standardisation and modelling have been widely used. The predicted mean vote (PMV) model is now most commonly used to predict and evaluate environmental thermal comfort [6]. The international standards of ISO 7730:2005 [7], ASHRAE 55:2017 [8], and EN16798:2019 [9] adopted the PMV model to evaluate indoor thermal environments. The physiological and physical parameters, including air temperature $\left(\mathrm{T}_{\mathrm{a}}\right)$, mean radiant temperature $\left(T_{r}\right)$, air velocity $\left(v_{a}\right)$, relative humidity $(H R)$, activity level (met), and clothing insulation (clo), were regarded as the main influential variables for 
thermal comfort in the PMV model. In this model, the neutral temperature is defined as the optimum condition where habitants do not want a warmer or colder environment.

However, many previous studies have found discrepancies between the PMV and the actual thermal sensation vote (TSV). Habitants have a wider acceptable temperature range in naturally ventilated buildings than that in air-conditioned buildings because of the dynamic response of thermal sensations to the outdoor microclimate $[10,11]$. There is a potential interaction between microclimates and human habitual adaptive behaviour, which adjusts to a comfortable indoor environment according to the occupants' thermal expectations [12]. The physical, physiological, and psychological parameters, as well as thermal preference, should be considered in the reaction description of the human body to the variable indoor thermal environment [13]. The authors of plenty of field studies have claimed that occupants' thermal comfort changes with block type, the indoor environment, and living habits [14-19]. Many studies have also found that differences exist in occupants thermal sensations in different areas and local microclimates [20-23]. Although previous field studies have been conducted on diverse building types in various locations and climates, each study has had unique sample characteristics.

Guilin $\left(109^{\circ} 36^{\prime} 50^{\prime \prime}-111^{\circ} 29^{\prime} 30^{\prime \prime} \mathrm{E}, 24^{\circ} 15^{\prime} 23^{\prime \prime}-26^{\circ} 23^{\prime} 30^{\prime \prime} \mathrm{N}\right)$ is located on areas of alluvial plains between the limestone towers in western China. The tower-shaped karsts of Guilin are the most beautiful landforms in China and the world [24]. Along both sides of the Lijiang River in the city centre of Guilin, many limestone towers of its well-known fenglin karst are lined up in an orderly formation and covered with verdant bush. In the city centre of Guilin, the residential buildings are mainly multi-storey houses that are no taller than seven storeys due to a height restriction policy of the Guilin government. Therefore, a unique architectural microclimate environment that potentially influences the occupants' thermal sensations was formed amongst the residential buildings, fenglin karst, plains, and rivers. However, most field studies performed on residential thermal comfort in China have focused on the developed plain cities in southern and central China and there has been no research done on thermal comfort in the karst areas. There are no generally recommended acceptable comfort range and specific thermal comfort prediction models for the existing residential buildings in undeveloped areas in western China, particularly in Guilin City.

In this study, we researched the possible correlations between the occupants' thermal sensations to on-site environmental monitoring and in situ measurements of multi-storey residential buildings under natural ventilation in the Guilin karst area in order to analyse the effect of the fenglin karst and river factors on the thermal comfort results and to develop a rigorous database for designing an optimal indoor thermal environment.

\section{Field Study Situation and Method}

\subsection{Climate}

Our study took place in the Guilin karst area. Guilin is located in a hot summer and cold winter climate (HSCW) zone in China. The Guilin area is characterised by a subtropical monsoon climate, which is dominated by the East Asian monsoon and characterised by two distinct seasons of a cold and rainy winter and a hot and rainy summer. The annual mean air temperature of Guilin City is $18.9^{\circ} \mathrm{C}$. The hottest months are July and August, with an average outdoor temperature of $28.2^{\circ} \mathrm{C}$, while the coldest month is January, the mean temperature of which was $8.1^{\circ} \mathrm{C}$ from 1951 to 2020 . The average annual rainy days and the average annual rainfall are 172.5 days and $1886 \mathrm{~mm}$, respectively. The rainy season lasts from April to August and accounts for $77.4 \%$ of the total rainfall. The maximum mean monthly outdoor relative humidity is $81 \%$ in June, while the minimum relative humidity is $66 \%$ in December. Figure 1 shows the meteorological data of a typical year in Guilin City. 


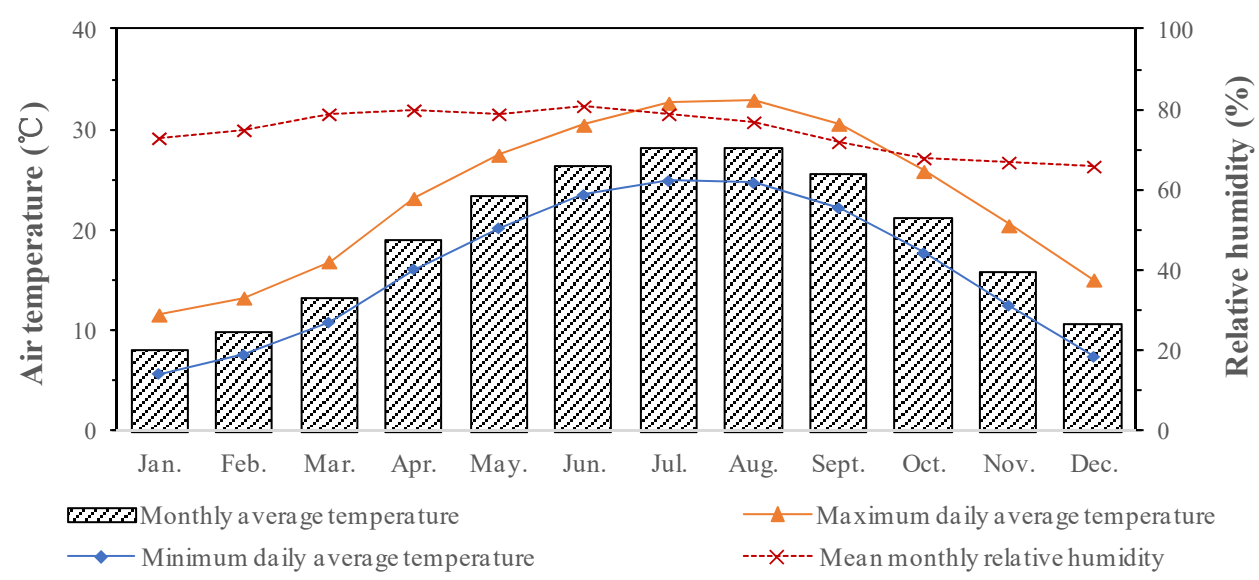

Figure 1. The meteorological data of typical year in Guilin City.

\subsection{Location and Description of the Buildings Surveyed}

To investigate neutral thermal comfort level and thermal preference, this study employed a questionnaire survey, in situ measurements, and environmental monitoring of 77 residential buildings in 20 residential sub-districts in Guilin city centre. In this study, the 20 residential sub-districts were divided into 3 categories: 4 residential sub-districts near fenglin karst (NF), 8 residential sub-districts near river (NR), and 8 residential subdistricts neither near fenglin karst nor near river (NN). The dwellings investigated in the 3 categories of residential sub-districts were abbreviated to dwelling NF, dwelling NR, and dwelling NN, respectively. Among the buildings surveyed in the study, brick-concrete structure and frame structure accounted for $42.5 \%$ and $55.5 \%$, respectively. Only $3.9 \%$ of buildings used external wall insulation; however, buildings with sun-shading accounted for about $76.9 \%$.

The surveys were conducted over 61 days during summer (from 1 August 2019 to 30 September 2019) and 42 days during winter (from 20 December 2019 to 31 January 2020). In total, 144 households and their dwellings were surveyed, 96 during summer ( 22 for $\mathrm{NF}, 35$ for NR, and 39 for NN) and 48 during winter (12 for NF, 17 for NR, and 19 for $\mathrm{NN}$ ). Indoor thermal environmental parameters were monitored concurrently when the questionnaire surveys were carried out with occupants sampled. One or two occupants in a dwelling were chosen. In summer, 145 occupants from 20 to 80 years of age participated in the study, $62.8 \%$ female and $37.2 \%$ male. The distribution of the participants in summer was as follows: 38 occupants from the dwelling NF (near fenglin karst), 45 occupants from the dwelling NR (near river), and 62 occupants from the dwelling NN (neither near fenglin karst nor near river). In winter, 78 occupants from 18 to 80 years of age participated in the study, $61.5 \%$ female and $38.5 \%$ male. The distribution of the participants in winter was as follows: 20 occupants from the dwelling NF, 25 occupants from the dwelling NR, and 33 occupants from the dwelling NN. Table 1 shows the characteristics of the participants in our study. The clothing insulation was calculated based on the standard ASHRAE 55 and individual survey.

The thermal environment for the main space for daily life (bedroom and living room) of each household was chosen as the research environment for both indoor physical parameters and questionnaire. The environment measurement and questionnaire survey were in the natural ventilation state. The air conditioning or heating equipment was not turned on. 
Table 1. The characteristics of the participants in our study.

\begin{tabular}{|c|c|c|c|c|c|c|}
\hline Season & Parameter & & Maximum & Minimum & Mean & Standard Deviation \\
\hline \multirow{10}{*}{ Summer } & \multirow{2}{*}{ Age (years) } & Male & 69 & 20 & 43.87 & 16.68 \\
\hline & & Female & 80 & 20 & 48.10 & 18.77 \\
\hline & \multirow{2}{*}{ Height (m) } & Male & 1.8 & 1.5 & 1.67 & 9.75 \\
\hline & & Female & 1.78 & 1.45 & 1.59 & 6.63 \\
\hline & \multirow{2}{*}{ Weight (kg) } & Male & 80 & 48 & 63.50 & 11.27 \\
\hline & & Female & 75 & 40 & 54.47 & 8.20 \\
\hline & \multirow{2}{*}{ Clothing insulation (clo) } & Male & 0.79 & 0.21 & 0.43 & 0.10 \\
\hline & & Female & 0.82 & 0.10 & 0.46 & 0.16 \\
\hline & \multirow{2}{*}{ Time living in Guilin (years) } & Male & 65 & 3 & 31.91 & 19.41 \\
\hline & & Female & 80 & 3 & 36.28 & 21.61 \\
\hline \multirow{10}{*}{ Winter } & \multirow{2}{*}{ Age (years) } & Male & 72 & 18 & 48.50 & 15.22 \\
\hline & & Female & 80 & 20 & 45.48 & 16.55 \\
\hline & \multirow{2}{*}{ Height (m) } & Male & 1.82 & 1.56 & 1.70 & 6.70 \\
\hline & & Female & 1.70 & 1.50 & 1.59 & 5.08 \\
\hline & \multirow{2}{*}{ Weight (kg) } & Male & 49 & 80 & 62.97 & 7.90 \\
\hline & & Female & 82 & 42 & 54.13 & 7.79 \\
\hline & \multirow{2}{*}{ Clothing insulation (clo) } & Male & 1.68 & 0.58 & 1.03 & 0.27 \\
\hline & & Female & 1.68 & 0.58 & 1.05 & 0.24 \\
\hline & \multirow{2}{*}{ Time living in Guilin (years) } & Male & 72 & 4 & 43.6 & 19.93 \\
\hline & & Female & 80 & 3 & 37.51 & 20.19 \\
\hline
\end{tabular}

\subsection{Environmental Parameters Measurements}

In the field study, the outdoor environmental conditions, including the outdoor air temperature $\left(\mathrm{t}_{\mathrm{a}}\right)$ and relative humidity $(\mathrm{RH})$, were monitored with a thermometer of a HOBO MX2300 series data logger (resolution $0.04{ }^{\circ} \mathrm{C}, \mathrm{RH} 0.05 \%$ ) to investigate the neutral thermal comfort for the climate of Guilin. The indoor environmental conditions were recorded using a thermometer of an AZ8829S data logger (resolution $0.1^{\circ} \mathrm{C}, \mathrm{RH} 0.1 \%$ ) and a hot-wire anemometer of ST733. The globe temperature $\left(\mathrm{t}_{\mathrm{g}}\right)$ was recorded with a $150 \mathrm{~mm}$ diameter globe thermometer (resolution $0.1^{\circ} \mathrm{C}$ ). Table 2 shows the variables monitored and information about the devices used, based on the conditions of instruments for measuring physical quantities in the standard of ISO 7726:1998 [25].

The assessment and analysis processes of the indoor thermal environment were according to the standards of ASHRAE 55 and GB 50785-2012 [26]. Data were measured at one central point if the indoor area was less than $16 \mathrm{~m}^{2}$. If the indoor area was between $16 \mathrm{~m}^{2}$ and $30 \mathrm{~m}^{2}$, data were measured at the two dividing points that divided the diagonal line of the space into three equal parts. Data were measured at three points when the indoor area was more than $30 \mathrm{~m}^{2}$. All instruments were checked, as required, before testing. They were placed far away from heat sources. The height of $1.1 \mathrm{~m}$ above the floor was selected at each point [27], and the measurement intervals were $1 \mathrm{~min}$.

Table 2. Monitoring instruments used in the survey.

\begin{tabular}{|c|c|c|c|c|c|}
\hline $\begin{array}{l}\text { Measurement } \\
\text { Instrument }\end{array}$ & Parameter & Measuring Range & Accuracy & Resolution & Sampling Interval \\
\hline HOBO MX2300 & $\begin{array}{c}\text { Outdoor temperature } \\
\text { Outdoor RH }\end{array}$ & $\begin{array}{c}-40 \text { to }+70{ }^{\circ} \mathrm{C} \\
0 \text { to } 100 \%\end{array}$ & $\begin{array}{l} \pm 0.2{ }^{\circ} \mathrm{C} \\
\pm 2.5 \%\end{array}$ & $\begin{array}{c}0.04{ }^{\circ} \mathrm{C} \\
0.05 \%\end{array}$ & $\begin{array}{l}1 \mathrm{~min} . \\
1 \mathrm{~min} .\end{array}$ \\
\hline AZ8829S & $\begin{array}{l}\text { Indoor temperature } \\
\text { Indoor RH }\end{array}$ & $\begin{array}{c}-40 \text { to }+85^{\circ} \mathrm{C} \\
0 \text { to } 100 \%\end{array}$ & $\begin{array}{c} \pm 0.6^{\circ} \mathrm{C} \\
\pm 3 \%\end{array}$ & $\begin{array}{l}0.1^{\circ} \mathrm{C} \\
0.1 \%\end{array}$ & $\begin{array}{l}1 \mathrm{~min} . \\
1 \mathrm{~min} .\end{array}$ \\
\hline SENTRY ST733 & Air velocity & 0 to $40 \mathrm{~m} / \mathrm{s}$ & $\pm 0.03 \mathrm{~m} / \mathrm{s}$ & $0.01 \mathrm{~m} / \mathrm{s}$ & $1 \mathrm{~min}$. \\
\hline JTSOFT-Meter JTR04 & Globe temperature & -20 to $125^{\circ} \mathrm{C}$ & $\pm 0.5^{\circ} \mathrm{C}$ & $0.1^{\circ} \mathrm{C}$ & $1 \mathrm{~min}$. \\
\hline
\end{tabular}




\subsection{Thermal Comfort Surveys}

The horizontal and longitudinal surveys were conducted simultaneously in the dwellings NF, NR, and NN. The participants were asked to complete the longitudinal questionnaire at least twice. The interval between two questionnaires should be more than $20 \mathrm{~min}$. Participants were asked to sit indoors for at least $15 \mathrm{~min}$ before the survey and then completed questionnaires. A total of 242 effective responses were collected over the summer survey period, 64 responses in the dwelling NF, 78 responses in the dwelling $\mathrm{NR}$, and 100 responses in the dwelling NN, while a total of 172 effective responses were collected over the winter survey period, 40 responses in the dwelling NF, 59 responses in the dwelling NR, and 73 responses in the dwelling NN.

The content of the questionnaire was explained by the surveyor face-to-face. If the participant (such as the elderly) was unable to write, the survey was conducted through an interview. The questionnaire included:

(1) Basic information of buildings and participants, e.g., surroundings environment, carpet area, insulation strategies, sun-shading, gender, age, clothing, height and weight, time living in Guilin, annual family income;

(2) Thermal subjective sensation vote: questionnaire options with 2 to 7 scales are listed in Table 3.

This study respects the fundamental principles established in the Declaration of Helsinki and was approved by the ethics committee of the Guilin University of Technology.

Table 3. Survey questionnaire options.

\begin{tabular}{ccc}
\hline Thermal Sensation & Preference & Acceptability \\
\hline Cold $(-3)$ & Warmer $(+1)$ & Acceptable $(+1)$ \\
Cool $(-2)$ & No change (0) & Unacceptable $(-1)$ \\
Slightly cool $(-1)$ & Cooler $(-1)$ & \\
Neutral $(0)$ & & \\
Slightly warm $(+1)$ & & \\
Warm $(+2)$ & & \\
Hot $(+3)$ & & \\
\hline
\end{tabular}

\section{Results and Discussion}

\subsection{Thermal Environmental Conditions}

Table 4 shows the average, minimum, and maximum values and their standard deviation of the indoor and outdoor variables recorded during the field study. As shown in Table 4 , the indoor air temperature $\left(\mathrm{t}_{\mathrm{a}, \text { in }}\right)$ varied between $26.5^{\circ} \mathrm{C}$ and $33.3^{\circ} \mathrm{C}$ with the mean value of $30.0 \pm 1.7^{\circ} \mathrm{C}$ during the summer survey and between $10.4^{\circ} \mathrm{C}$ and $22.8^{\circ} \mathrm{C}$ with the mean value of $16.1 \pm 2.6^{\circ} \mathrm{C}$ during the winter. The average indoor relative humidity $\left(\mathrm{RH}_{\text {in }}\right)$ was about $46.0 \%$ and $63.6 \%$ during summer and winter, respectively. The maximum outdoor air temperature $\left(\mathrm{t}_{\mathrm{a}, \mathrm{out}}\right)$ was $33.3 \pm 1.9^{\circ} \mathrm{C}$ during summer, while it was about $20.8 \pm 3.1{ }^{\circ} \mathrm{C}$ during the cold period.

The variations of the indoor thermal environment in the dwellings NF, NR, and NN are shown in Figure 2. In summer, regarding the $t_{a, \text { in }}$ and the globe temperature $\left(t_{\mathrm{g}}\right)$, similar values were monitored in the dwellings $N F, N R$, and $N N$, although the $t_{a, \text { in }}$ fluctuation was larger in the dwelling $\mathrm{NN}$. The average $\mathrm{RH}_{\text {in }}$ in the dwelling $\mathrm{NF}$ was the lowest at about $30.5 \%$, which was approximately $20 \%$ lower than that in the dwellings NR and NN. In winter, the average $t_{a}$,in and the average $t_{g}$ in the dwelling NF were the lowest, and those in the dwelling NR were the highest. No significant diversity was observed in the average $\mathrm{RH}_{\text {in }}$ in the spaces. The most unstable indoor thermal environment occurred in the dwelling NN. 
Table 4. Thermal physical variables during the field study.

\begin{tabular}{ccccccccc}
\hline \multirow{2}{*}{ Season } & $\begin{array}{c}\text { Statistical } \\
\text { Information }\end{array}$ & $\mathbf{t}_{\mathbf{a}, \text { in }}\left({ }^{\circ} \mathbf{C}\right)$ & $\mathbf{R H}_{\mathbf{i n}}(\mathbf{\%})$ & $\mathbf{t}_{\mathbf{a}, \text { in }}(\mathbf{m} / \mathbf{s})$ & $\mathbf{t}_{\mathbf{g}}\left({ }^{\circ} \mathbf{C}\right)$ & $\mathbf{t}_{\mathbf{o p}}\left({ }^{\circ} \mathbf{C}\right)$ & $\mathbf{t}_{\mathbf{a}, \mathbf{o u t}}\left({ }^{\circ} \mathbf{C}\right)$ & $\mathbf{R} \mathbf{H}_{\mathbf{o u t}}\left({ }^{\circ} \mathbf{C}\right)$ \\
\hline \multirow{3}{*}{ Summer } & Maximum & 33.3 & 74.3 & 0.58 & 33.1 & 33.1 & 33.3 & 88.8 \\
& Minimum & 26.5 & 23.5 & 0.00 & 25.6 & 26.4 & 25.4 & 32.0 \\
& Mean & 30.0 & 46.0 & 0.02 & 29.5 & 29.7 & 29.3 & 62.0 \\
\multirow{2}{*}{ Winter } & S.D. & 1.7 & 15.3 & 0.09 & 1.6 & 1.6 & 1.9 & 12.8 \\
& Maximum & 22.8 & 76.5 & 0.16 & 21.2 & 21.4 & 20.8 & 94.3 \\
& Minimum & 10.4 & 48.6 & 0.00 & 11.5 & 11.2 & 5.6 & 40.8 \\
& Mean & 16.1 & 63.6 & 0.00 & 16.5 & 16.4 & 10.2 & 72.9 \\
\hline
\end{tabular}

Note: $t_{a, i n}$-Indoor air temperature, $\mathrm{RH}_{\mathrm{in}}$-Indoor relative humidity, $\mathrm{v}_{\mathrm{a}, \text { in }}$-Indoor air speed, $\mathrm{t}_{\mathrm{g}}$-Globe temperature, $\mathrm{t}_{\mathrm{op}}$-Operative temperature, $\mathrm{t}_{\mathrm{a}, \mathrm{out}}$-Outdoor air temperature, $\mathrm{RH}_{\mathrm{out}}$ - Outdoor relative humidity, S.D. - Standard deviation.

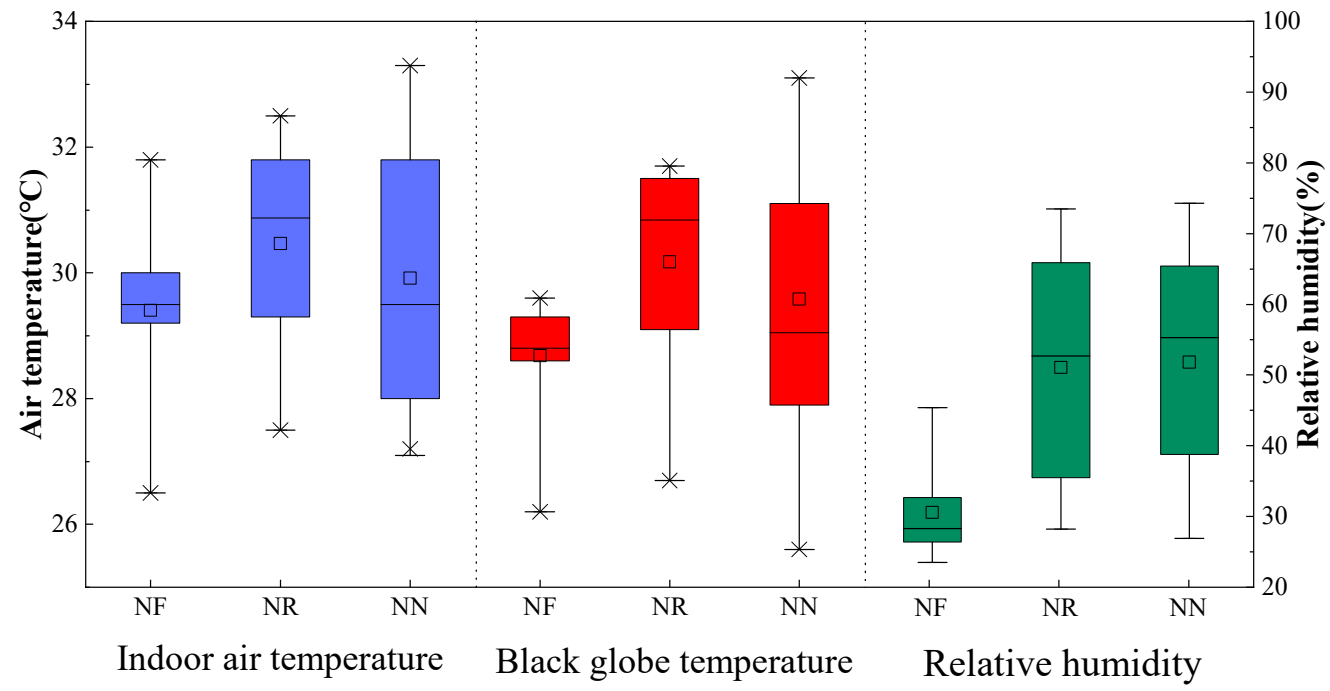

(a)

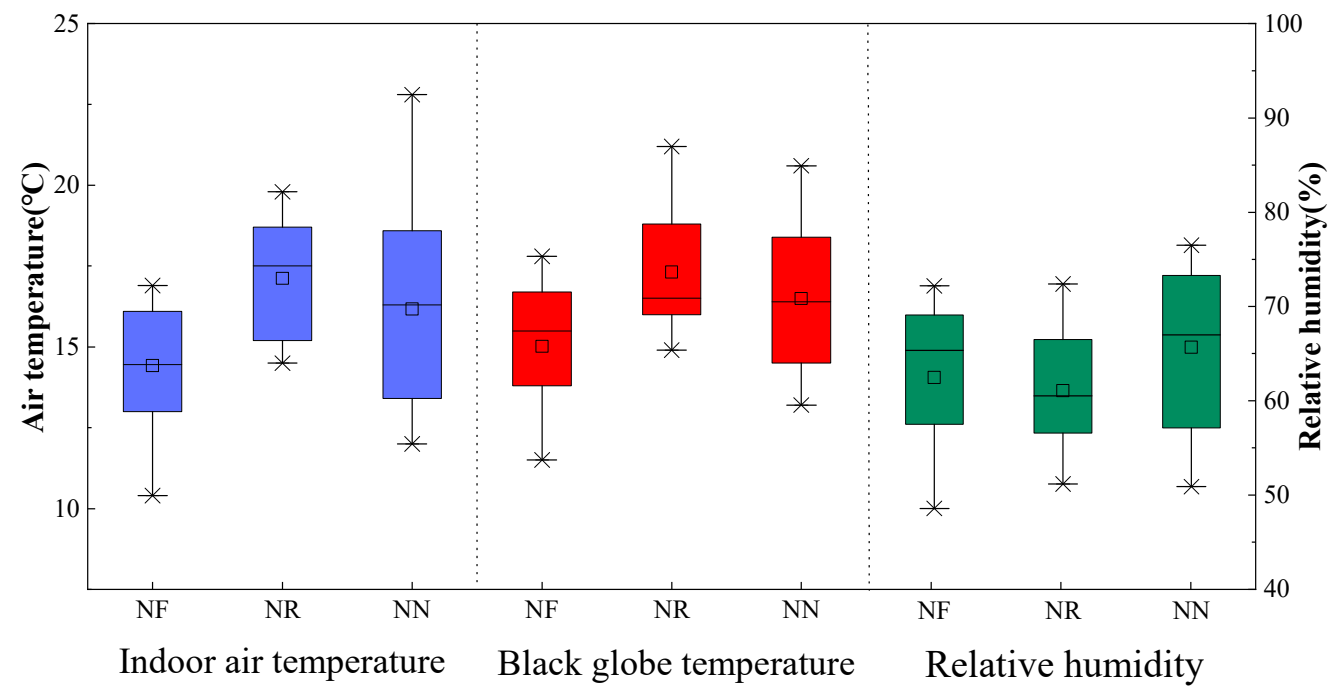

(b)

Figure 2. Variations of indoor thermal environment in the dwellings NF, NR, and NN. (a) Summer; (b) Winter. 


\subsection{Thermal Comfort Survey Response}

\subsubsection{Distribution of Thermal Sensation Votes (TSV)}

In the surveys, the thermal sensation votes (TSV) were applied to respond and evaluate how comfortable the subjects found the temperature in their home according to the widely used ASHRAE thermal comfort scale (as shown in Table 3).

The distribution of TSV is shown in Figure 3. The majority of the participants reported a hot thermal sensation accounting for $43.7 \%$ in summer, and a neutral thermal sensation accounting for $49.1 \%$ in winter during the interviews. It is generally the case that people voting within the central three categories of thermal sensation $(-1,0$, and +1$)$ are considered comfortable [28]. In the survey, more than $81 \%$ of the votes in winter were within the comfort range of TSV $(-1,0$, and +1$)$, while only $53 \%$ of the votes of comfort were in summer.

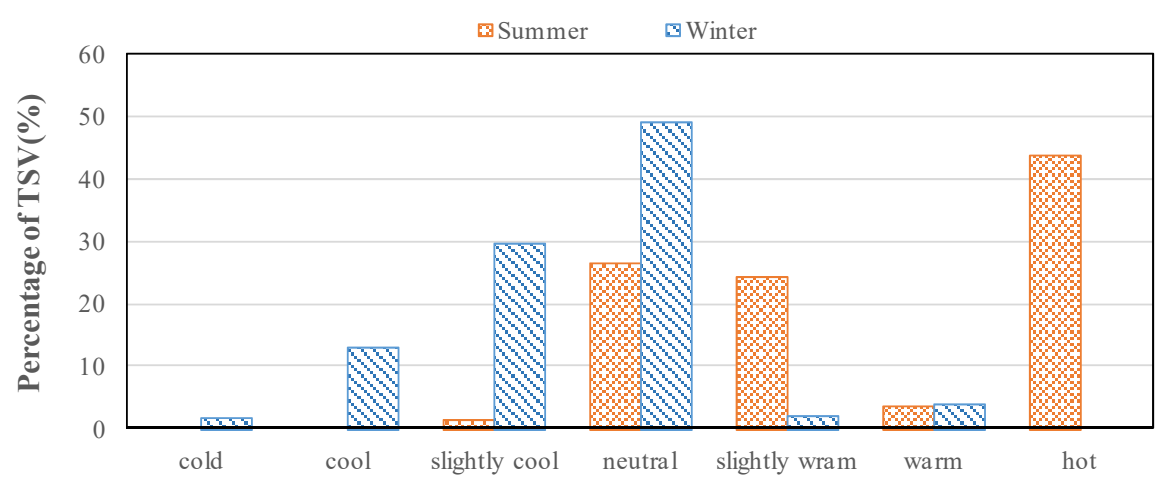

Figure 3. The percentage of occupants' thermal sensation votes in Guilin karst area.

\subsubsection{Predicted Mean Votes (PMV) and TSV}

The mathematical equations for PMV were determined by the principle of human body heating balance [6,7] (Equations (1) and (2)). We computed the PMV value with the code edited by the statistical programming language $\mathrm{VB}$ and validated it by the known input-outputs. For the dwellings in the Guilin karst area, the average TSV and PMV values were 1.42 and 1.60 , respectively, in summer and -0.50 and -0.31 , respectively, in winter, as shown in Figure 4.

$$
\mathrm{PMV}=\left[0.303 \mathrm{e}^{-0.036 \mathrm{M}}+0.028\right] \mathrm{L}
$$

where $\mathrm{L}$ is the body thermal load $\left(\mathrm{W} / \mathrm{m}^{2}\right)$.

$$
\begin{gathered}
\mathrm{L}=(\mathrm{M}-\mathrm{W})-3.05 \times\left[5.733-0.007(\mathrm{M}-\mathrm{W})-\mathrm{P}_{\mathrm{a}}\right]-0.42(\mathrm{M}-\mathrm{W}-58.15)-0.0173 \mathrm{M}\left(5.87-\mathrm{P}_{\mathrm{a}}\right) \\
-0.0014\left(34-\mathrm{t}_{\mathrm{a}}\right)-3.96 \times 10^{-8} \mathrm{f}_{\mathrm{cl}}\left[\left(\mathrm{t}_{\mathrm{cl}}+273\right)^{4}-\left(\mathrm{t}_{\mathrm{mrt}}+273\right)^{4}\right]-\mathrm{f}_{\mathrm{cl}} \mathrm{h}_{\mathrm{c}}\left(\mathrm{t}_{\mathrm{cl}}-\mathrm{t}_{\mathrm{a}}\right)
\end{gathered}
$$

where $\mathrm{M}$ is the metabolic rate $\left(\mathrm{W} / \mathrm{m}^{2}\right) ; \mathrm{W}$ is useful work $\left(\mathrm{W} / \mathrm{m}^{2}\right) ; \mathrm{P}_{\mathrm{a}}$ is partial pressure of water vapour $(\mathrm{mmHg}) ; \mathrm{t}_{\mathrm{a}}$ is air temperature $\left({ }^{\circ} \mathrm{C}\right) ; \mathrm{f}_{\mathrm{cl}}$ is dressing area coefficient determined by the clothing thermal resistance $\mathrm{I}_{\mathrm{cl}}\left(\mathrm{f}_{\mathrm{cl}}=1+0.3 \mathrm{I}_{\mathrm{cl}}\right) ; \mathrm{t}_{\mathrm{cl}}$ is surface temperature of clothing $\left({ }^{\circ} \mathrm{C}\right) ; \mathrm{t}_{\mathrm{mrt}}$ is mean radiant temperature $\left({ }^{\circ} \mathrm{C}\right)$; and $\mathrm{h}_{\mathrm{c}}$ is convective heat transfer coefficient $\left(\mathrm{W} / \mathrm{m}^{2}{ }^{\circ} \mathrm{C}\right)$.

The violin plots in Figure 5 show the probability density of the data for both PMV and TSV for the range of possible values on the vote scale (from -3 to +3 ) in the dwellings NF, $\mathrm{NR}$, and NN. In summer, percentages of the TSV in the interval $[-1,+1]$ in the dwellings NF, $\mathrm{NR}$, and NN were $35 \%, 35 \%$, and $29 \%$, respectively. In winter, their percentages were $87 \%$, $90 \%$, and $74 \%$, respectively. The classical PMV model under-predicted the true comfort of participants due to the significant differences between TSV and PMV. Additionally, the TSV showed a much narrower range. 


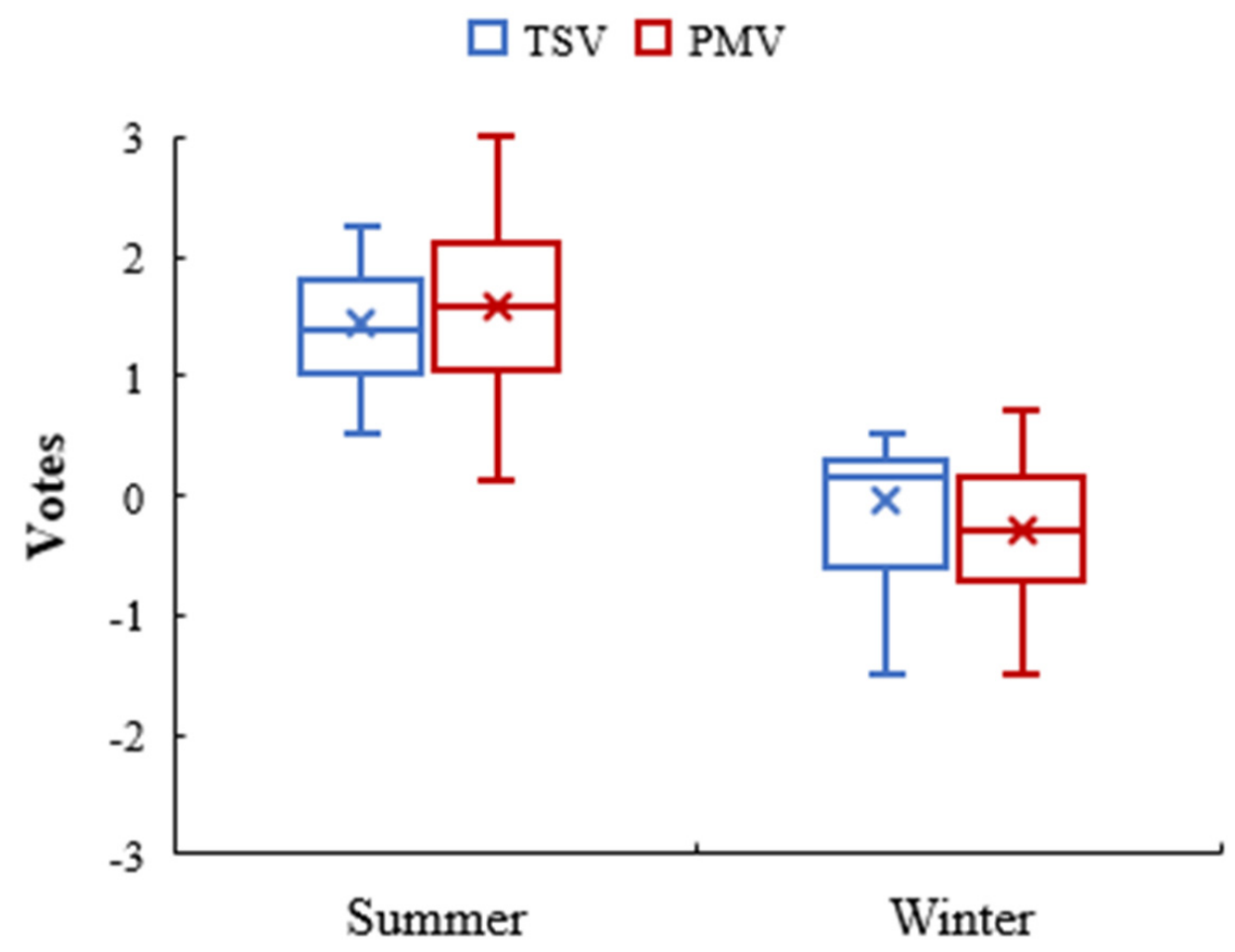

Figure 4. Thermal sensation votes (TSV) and predicted mean votes (PMV) in summer and winter.

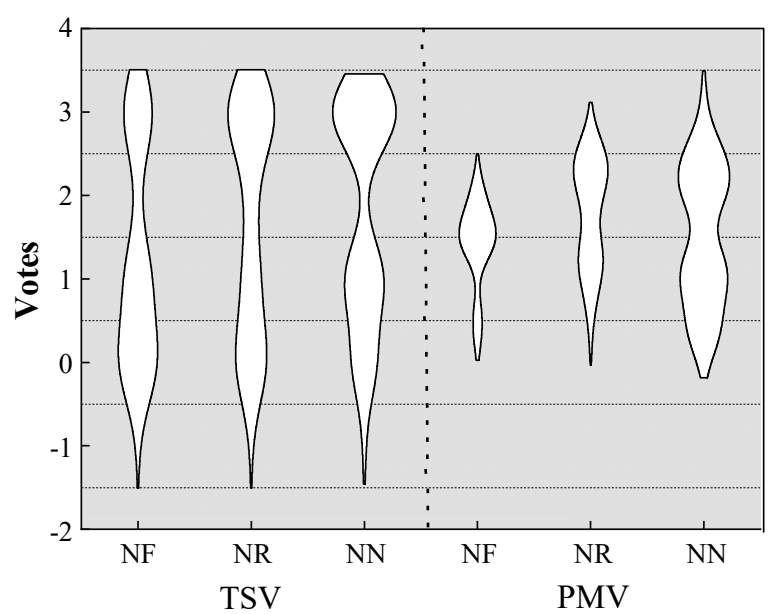

(a)

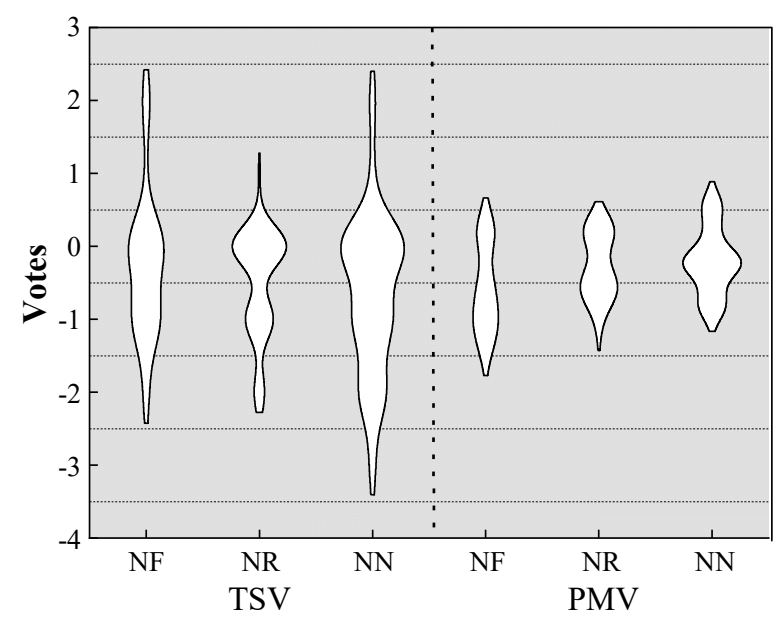

(b)

Figure 5. Density plots for TSV and PMV of the dwellings NF, NR, and NN. (a) Summer; (b) Winter.

\subsection{Comfort and Preferred Temperature}

\subsubsection{Regression Method and Comparison between TSV and PMV}

As is confirmed by references $[29,30]$, the mean radiant temperature $\left(t_{m r t}\right)$ and the air temperature $\left(t_{a}\right)$ influence the uncertainty in thermal comfort evaluation. It was nonuniform that the radiant temperature distributed on the globe thermometers [31]. In order to reduce the uncertainty, the operative temperature $\left(t_{o p}\right)$, which is a synthetic temperature comprehensively being considered as the effects of $t_{\mathrm{a}}$ and $t_{\mathrm{mrt}}$ on the thermal perception of the human body, was recommended for use [29]. The $t_{o p}$ is calculated as in Equation (3) [32]:

$$
t_{o p}=A \times t_{a}+(1-A) \times t_{m r t}
$$


where $t_{o p}$ is operative temperature $\left({ }^{\circ} \mathrm{C}\right) ; t_{a}$ is air temperature $\left({ }^{\circ} \mathrm{C}\right) ; t_{m r t}$ is mean radiant temperature $\left({ }^{\circ} \mathrm{C}\right)$; and $\mathrm{A}$ is the average weight factor of the $\mathrm{t}_{\mathrm{a}}$ and $\mathrm{t}_{\mathrm{mrt}}$.

Under the natural convection condition, the $t_{m r t}$ was calculated as in Equation (4) [33]:

$$
\mathrm{t}_{\mathrm{mrt}}=\left[\left(\mathrm{t}_{\mathrm{g}}+273\right)^{4}+0.4 \times 10^{8}\left|\mathrm{tg}_{\mathrm{g}}-\mathrm{t}_{\mathrm{a}}\right|^{\frac{1}{4}} \times\left(\mathrm{tg}_{\mathrm{g}}-\mathrm{t}_{\mathrm{a}}\right)\right]^{\frac{1}{4}}-273
$$

where $t_{m r t}$ is mean radiant temperature $\left({ }^{\circ} \mathrm{C}\right)$; $t_{g}$ is globe temperature $\left({ }^{\circ} \mathrm{C}\right)$; and $t_{a}$ is air temperature $\left({ }^{\circ} \mathrm{C}\right)$.

To compare the TSV and the PMV, the whole range of $t_{\mathrm{op}}$ was used to analyse the variation of the data. A scatter diagram of $t_{\mathrm{op}}$ and TSV and PMV for dwellings surveyed in the Guilin karst area was planned and equations of linear regression were established, as shown in Figure 6. The intervals of $1{ }^{\circ} \mathrm{C}$ were defined for the $t_{\mathrm{op}}$.

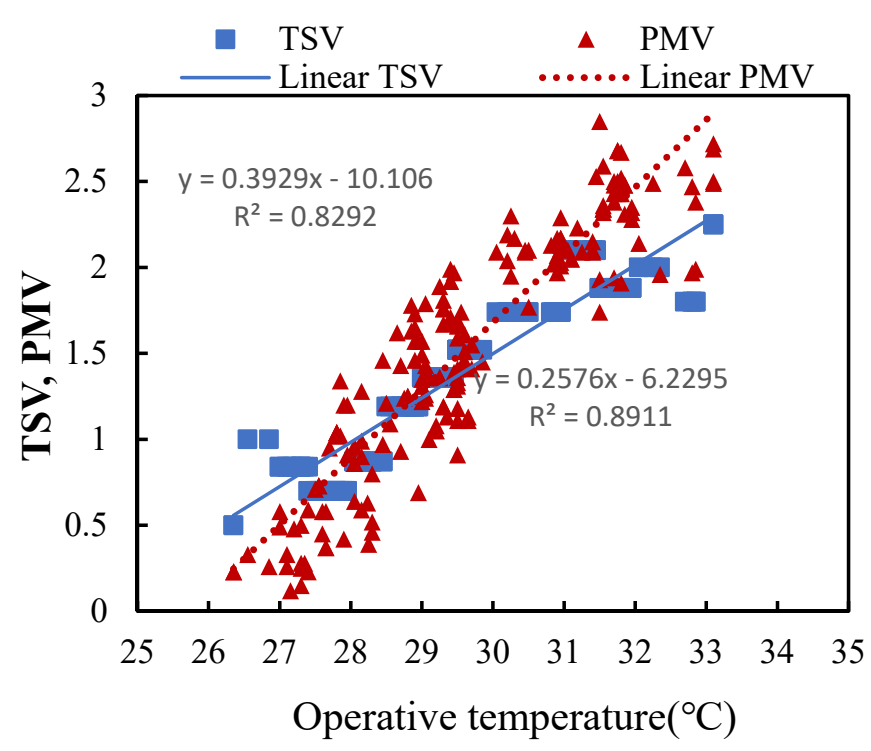

(a)

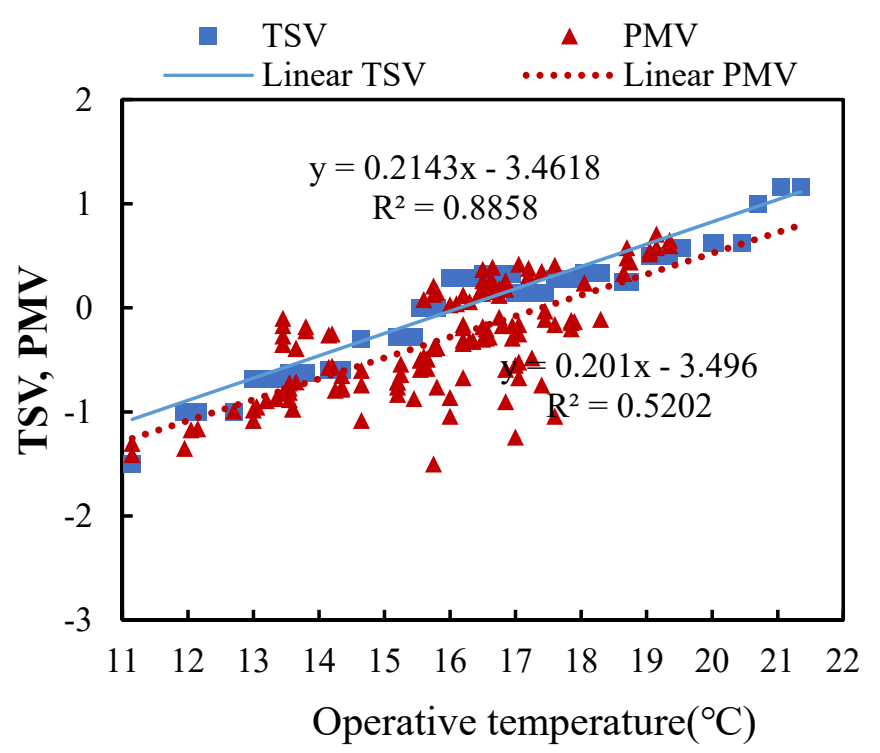

(b)

Figure 6. Relationship between participants' TSV/PMV and operative temperature in the survey dwellings in Guilin karst area. (a) Summer; (b) Winter.

In summer, the linear regression equation for the mean TSV was TSV $=0.2576 \mathrm{t}_{\mathrm{op}}-6.2295$ $\left(R^{2}=0.8911\right)$ and for the PMV was PMV $=0.3929 t_{\text {op }}-10.106\left(R^{2}=0.8292\right)$, as shown in Figure 6a. Additionally, as $\mathrm{t}_{\mathrm{op}}$ increased at the interval of $\mathrm{t}_{\mathrm{op}}<28.7^{\circ} \mathrm{C}$, the difference between PMV and TSV decreased gradually. While $t_{o p}$ increased at the interval of $t_{o p}>28.7^{\circ} \mathrm{C}$, the difference between PMV and TSV increased. In winter, the linear regression equations were TSV $=0.2143 \mathrm{t}_{\mathrm{op}}-3.4618\left(\mathrm{R}^{2}=0.8858\right)$ and PMV $=0.201 \mathrm{t}_{\mathrm{op}}-3.496\left(\mathrm{R}^{2}=0.5202\right)$ for the TSV and PMV, respectively, as shown in Figure 6b. The two regression lines of TSV and PMV were almost parallel.

To further investigate the effect of the fenglin karst and river factors on the results, the data were analysed independently for TSV and PMV in the dwellings NF, NR, and NN, respectively, as shown in Figure 7. In summer, six regression lines were found to intersect at around the point value of $t_{o p}=29^{\circ} \mathrm{C}$. At the interval of $t_{o p}<29^{\circ} \mathrm{C}$, the three regression lines of TSV in dwellings NF, NR, and NN were higher than the PMV, while at the interval of $t_{\text {op }}>29^{\circ} \mathrm{C}$, the TSV was overestimated in the PMV values. In winter, the TSV always was underestimated in the PMV values. Similarly, Yang [34] found that the PMV for the elderly was lower than the TSV in winter and was higher than the TSV in summer under a naturally ventilated condition. Alike results were also confirmed in surveys for naturally ventilated residential and office buildings by Dhaka [35]. 
The regression and Griffiths' methods are the two main methods to identify thermal comfort temperature. In this study, occupants' acceptance of the indoor thermal environment and their neutral estimates were calculated by the linear regression method, as shown in Figures 6 and 7. All the regression equations passed the goodness of fit $\left(R^{2}>0.5\right)$. When the regression equation equals zero, the calculated temperature can be considered as the neutral temperature $\left(t_{n}\right)$ of participants. Their accepted temperature $\left(t_{a c}\right)$ range of $80 \%$ is $-0.85<\mathrm{TSV}<+0.85[36]$.

Table 5 shows the actual and predicted $t_{n}$ and $t_{a c}$ in the dwellings NF, NR, and NN during summer and winter. The actual $t_{n}$ was lower than the predicted $t_{n}$ in the dwellings $\mathrm{NF}$, NR, and NN, respectively. Yao [37] and Yu [38] proposed similar results in different buildings and different climates by their previous research. In summer, there was no significant difference of the $t_{n}$ between the dwellings NF, NR, and NN. In winter, the $t_{n}$ in the dwelling NF was the lowest in all of the dwellings. The range of actual $\mathrm{t}_{\mathrm{ac}}(80 \%)$ calculated by the regression method in summer and winter was from 20.9 to $27.5^{\circ} \mathrm{C}$ and from 12.2 to $20.1^{\circ} \mathrm{C}$, respectively, as shown in Table 5 .

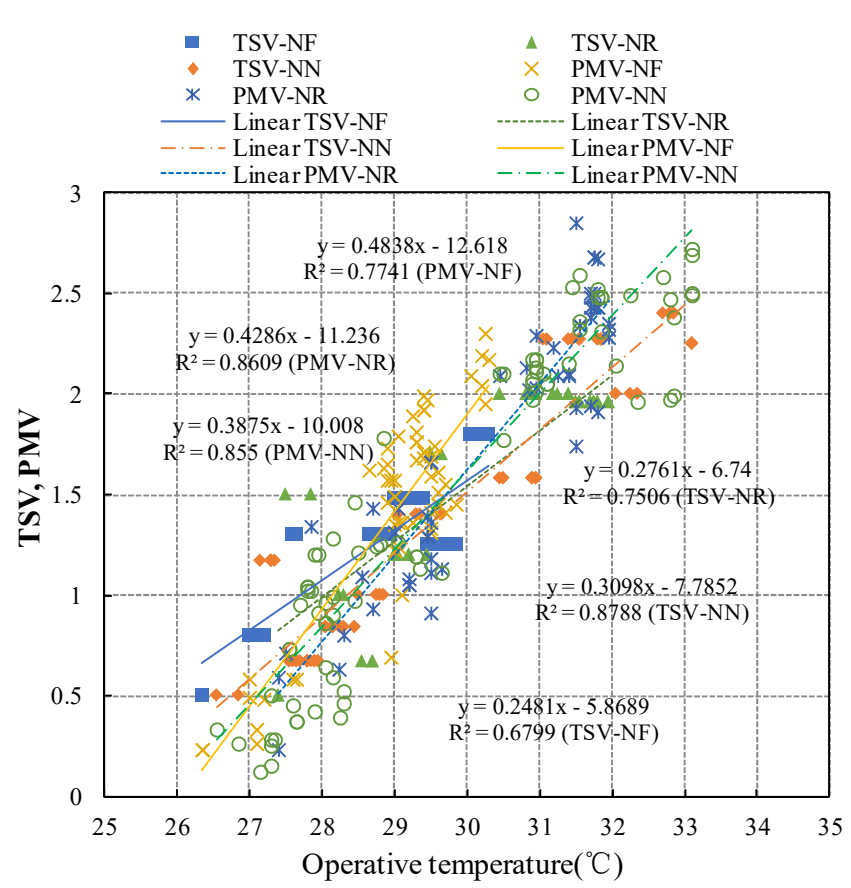

(a)

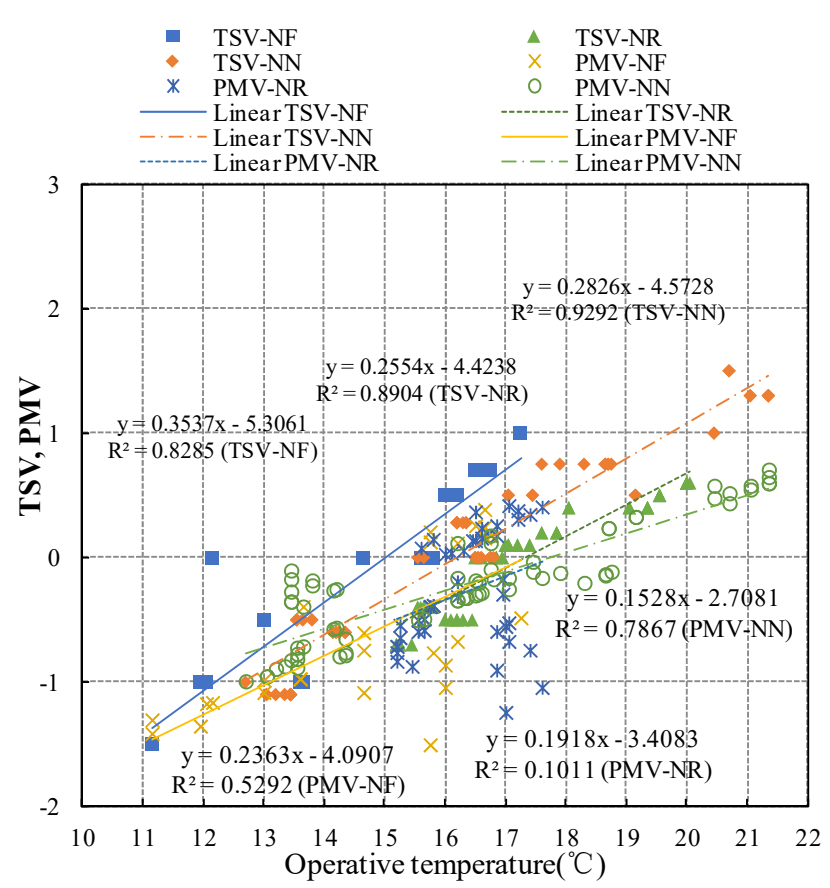

(b)

Figure 7. Relationship between participants' TSV/PMV and operative temperature in the dwellings NF, NR, and NN spaces. (a) Summer; (b) Winter.

Table 5. Neutral temperatures calculated by the regression method.

\begin{tabular}{cccccccccc}
\hline \multirow{2}{*}{ Season } & \multirow{2}{*}{ Parameter } & \multicolumn{9}{c}{ TSV } & \multicolumn{4}{c}{ PMV } \\
\cline { 2 - 10 } & & Total & NF & NR & NN & Total & NF & NR & NN \\
\hline \multirow{2}{*}{ Summer } & $\tan _{\mathrm{n}}{ }^{2}\left({ }^{\circ} \mathrm{C}\right)$ & 24.2 & 23.7 & 24.4 & 25.1 & 25.7 & 26.1 & 26.2 & 25.8 \\
& $\mathrm{t}_{\mathrm{ac}}{ }^{2}\left({ }^{\circ} \mathrm{C}\right)$ & $20.9-27.5$ & $20.2-27.1$ & $21.3-27.5$ & $22.4-27.9$ & $23.6-27.9$ & $24.3-27.8$ & $24.2-28.2$ & $23.6-28.0$ \\
\hline \multirow{2}{*}{ Winter } & $\mathrm{t}_{\mathrm{n}}\left({ }^{\circ} \mathrm{C}\right)$ & 16.2 & 15.0 & 17.3 & 16.2 & 17.4 & 17.3 & 17.8 & 17.7 \\
& $\mathrm{t}_{\mathrm{ac}}\left({ }^{\circ} \mathrm{C}\right)$ & $12.2-20.1$ & $12.6-17.4$ & $14.0-20.6$ & $13.2-19.2$ & $13.2-21.6$ & $13.7-20.9$ & $13.3-22.2$ & $12.2-23.3$ \\
\hline
\end{tabular}

\footnotetext{
${ }^{1} t_{n}$-Neutral temperature. ${ }^{2} t_{a c}$-Accepted temperature (80\%).
} 


\subsubsection{Preferred Temperature}

The occupants' preferred temperature $\left(t_{p}\right)$ was explored to be compared with their actual $t_{n}$. For the purpose, the "probit" analysis was conducted for the thermal preferred votes (TPV) and their corresponding $t_{o p}$. Probit regression analysis was first presented by Webb [39]. It is generally applied to illustrate the probability of an objective for data with binary response variables. Based on the investigation, the overall TPV were divided into two parts as preferences for cooler (assigned " -1 ") and preferences for warmer (assigned " +1 ") surroundings. The result of cumulation of TPV was set as " 1 " according to the Probit analysis. The $t_{p}$ was identified as the intersection point of the curve with "cooler" preference and the curve with "warmer" preference [40], as shown in Figure 8.

The $t_{p}$ in summer and winter were $25.8{ }^{\circ} \mathrm{C}$ and $18.6{ }^{\circ} \mathrm{C}$, respectively. The result displayed an obvious difference between the $t_{p}$ and the actual $t_{n}$. In accordance with the analysis, $t_{p}$ was around $1.6^{\circ} \mathrm{C}$ higher than the actual $t_{n}$ in summer and $2.4^{\circ} \mathrm{C}$ in winter. The analysis result clarified that occupants have a tendency towards warmer indoor environments for their $t_{p}$ in Guilin.

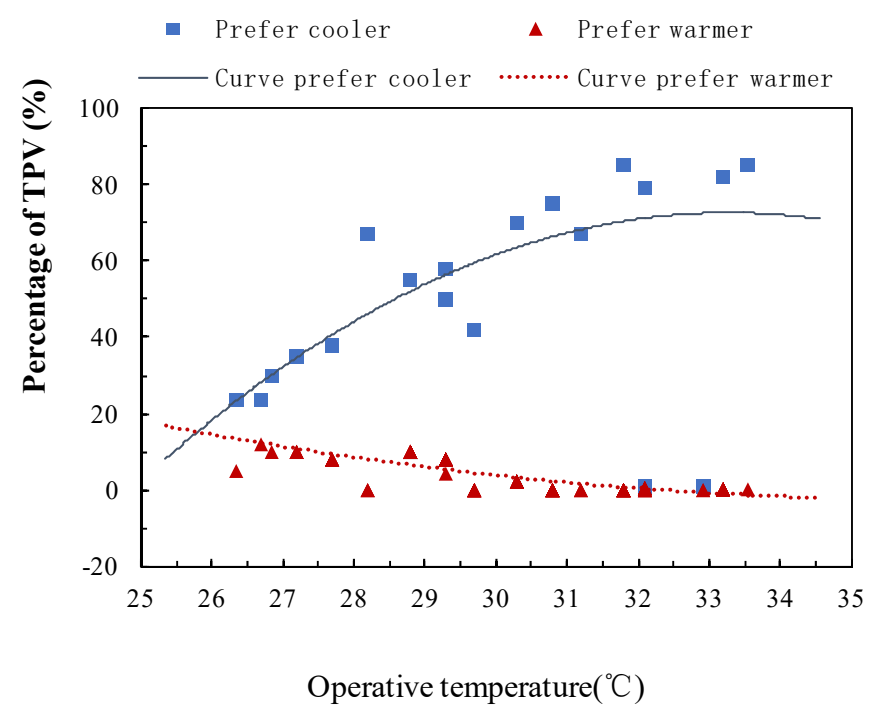

(a)

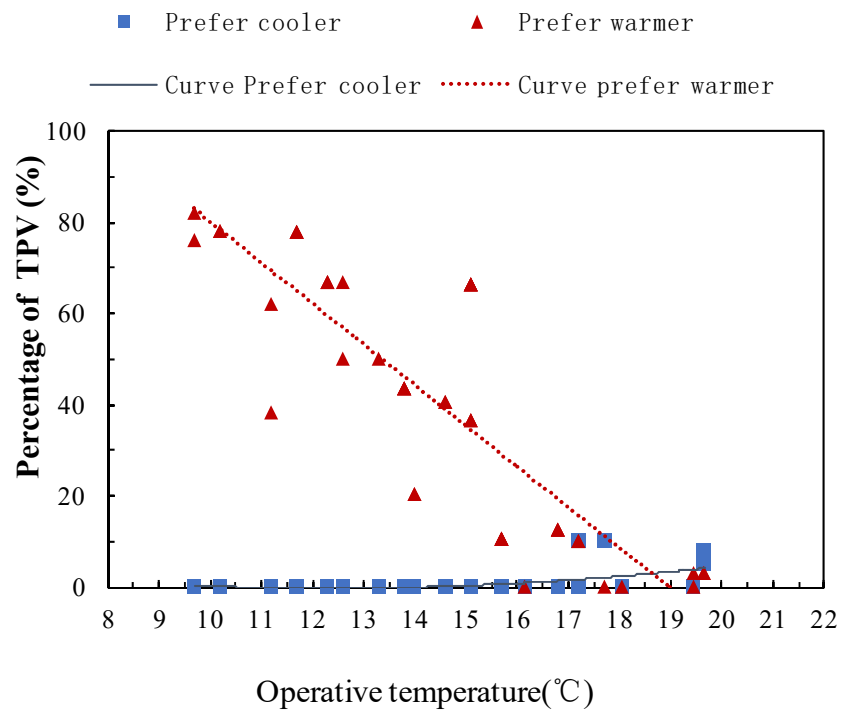

(b)

Figure 8. Preferred temperature for the dwellings. (a) Summer; (b) Winter.

\subsubsection{Thermal Comfort Characteristics Comparison with Previous Studies}

Table 6 summarises the discrepancy of $t_{n}, t_{a c}(80 \%)$, and TSV equations in the previous field studies $[4,41-49]$ which were conducted in naturally ventilated buildings of various climates and locations in China. As the results of comparison among the SC/C (severe cold/cold), HSCW (hot summer and cold winter), and HSWW (hot summer and warm winter) zones, occupants' $t_{\mathrm{n}}$ and the maximum of $t_{\mathrm{ac}}$ generally increased when the outdoor atmosphere became warmer. In the HSCW zone, both $t_{n}$ and $t_{a c}$ were higher in other cities than those in the Guilin karst area in summer due to the potential impact of the fenglin karst and the unique microclimate of the surroundings in Guilin. The results also presented that the occupants' $t_{a c}$ ranges of indoor thermal environment under natural convection in a HSCW climate zone were different. Hence, the design $t_{a c}$ range of different locations in the HSCW zone should be varied, which was in contradiction with the Chinese standard [26]. 
Table 6. Thermal comfort characteristics in different locations.

\begin{tabular}{|c|c|c|c|c|c|c|}
\hline Author & Location & Zone & Season & $t_{n}\left({ }^{\circ} \mathrm{C}\right)$ & $\mathrm{t}_{\mathrm{ac}}\left({ }^{\circ} \mathrm{C}\right)$ & TSV Equations \\
\hline \multirow{3}{*}{ Shao et al. [41] } & Harbin & $\mathrm{SC} / \mathrm{C}^{1}$ & Winter & 16.8 & $14.6-19.1$ & $\mathrm{TSV}=0.2203 \mathrm{t}_{\mathrm{op}}-3.7013, \mathrm{R}^{2}=0.9568$ \\
\hline & Changchun & $\mathrm{SC} / \mathrm{C}$ & Winter & 16.4 & $14.4-18.6$ & $\mathrm{TSV}=0.2467 \mathrm{t}_{\mathrm{op}}-4.0579, \mathrm{R}^{2}=0.9625$ \\
\hline & Shenyang & $\mathrm{SC} / \mathrm{C}$ & Winter & 16.0 & $13.9-18.2$ & $\mathrm{TSV}=0.2322 \mathrm{t}_{\mathrm{op}}-3.715, \mathrm{R}^{2}=0.9438$ \\
\hline Zhu et al. [42] & Dalian & $\mathrm{SC} / \mathrm{C}$ & Winter & 20.4 & $17.4-24.2$ & $\mathrm{TSV}=0.451 \mathrm{t}_{\mathrm{op}}-9.217, \mathrm{R}^{2}=0.946$ \\
\hline \multirow{2}{*}{ This study } & \multirow{2}{*}{ Guilin } & \multirow{2}{*}{$\mathrm{HSCW}^{2}$} & Summer & 24.2 & $20.9-27.5$ & $\mathrm{TSV}=0.2576 \mathrm{t}_{\mathrm{op}}-6.2295, \mathrm{R}^{2}=0.8911$ \\
\hline & & & Winter & 16.2 & $12.2-20.1$ & $\mathrm{TSV}=0.2143 \mathrm{t}_{\mathrm{op}}-3.4618, \mathrm{R}^{2}=0.8858$ \\
\hline \multirow{2}{*}{ Liu et al. [4] } & \multirow{2}{*}{$\begin{array}{l}\text { Chongqing, } \\
\text { etc. }\end{array}$} & \multirow{2}{*}{ HSCW } & Summer & 24.3 & \multirow{2}{*}{ / } & $\mathrm{TSV}=0.155 \mathrm{t}_{\mathrm{op}}-3.76, \mathrm{R}^{2}=0.93$ \\
\hline & & & Winter & 21.0 & & $\mathrm{TSV}=0.066 \mathrm{t}_{\mathrm{op}}-1.39, \mathrm{R}^{2}=0.93$ \\
\hline \multirow{2}{*}{ Xu et al. [43] } & \multirow{2}{*}{ Nanjing } & \multirow{2}{*}{ HSCW } & Summer & 28.0 & $22.0-30.1$ & $\mathrm{TSV}=0.2347 \mathrm{t}_{\mathrm{op}}-6.5646, \mathrm{R}^{2}=0.19323$ \\
\hline & & & Winter & 15.8 & $10.6-28.5$ & $\mathrm{TSV}=0.0949 \mathrm{t}_{\mathrm{op}}-1.5039, \mathrm{R}^{2}=0.1284$ \\
\hline \multirow{2}{*}{ Yan et al. [44] } & \multirow{2}{*}{$\begin{array}{c}\text { Shanghai, } \\
\text { etc. }\end{array}$} & \multirow{2}{*}{ HSCW } & Summer & 27.6 & \multirow{2}{*}{ / } & $\mathrm{TSV}=0.3552 \mathrm{t}_{\mathrm{op}}-9.8026, \mathrm{R}^{2}=0.96$ \\
\hline & & & Winter & 18.2 & & $\mathrm{TSV}=0.1477 \mathrm{t}_{\mathrm{op}}-2.6905, \mathrm{R}^{2}=0.86$ \\
\hline \multirow{2}{*}{ Li et al. [45] } & \multirow{2}{*}{$\begin{array}{l}\text { Wuhan, } \\
\text { etc. }\end{array}$} & \multirow{2}{*}{ HSCW } & Summer & 27.6 & \multirow{2}{*}{$16.3-28.1$} & $\mathrm{TSV}=0.3485 \mathrm{t}_{\mathrm{op}}-9.6190, \mathrm{R}^{2}=0.8309$ \\
\hline & & & Winter & 17.5 & & $\mathrm{TSV}=0.2235 \mathrm{t}_{\mathrm{op}}-3.9113, \mathrm{R}^{2}=0.6290$ \\
\hline Wu et al. [46] & Changsha & HSCW & Summer & 26.7 & $\leq 29.4$ & $\mathrm{TSV}=0.18 \mathrm{t}_{\mathrm{op}}-4.86, \mathrm{R}^{2}=0.74$ \\
\hline Zhang et al. [47] & Guangzhou & $\mathrm{HSWW}^{3}$ & Summer & 27.1 & $24.5-29.0$ & / \\
\hline Lu et al. [48] & Hainan & HSWW & Summer & 26.1 & $23.1-29.1$ & $\mathrm{TSV}=0.2855 \mathrm{t}_{\mathrm{op}}-7.4513, \mathrm{R}^{2}=0.9683$ \\
\hline Hwang et al. [49] & Taiwan & HSWW & Summer & 25.2 & $23.2-27.1$ & $\mathrm{TSV}=0.39 \mathrm{t}_{\mathrm{op}}-9.84, \mathrm{R}^{2}=0.91$ \\
\hline
\end{tabular}

${ }^{1}$ SC/C-Severe cold zone/Cold zone. ${ }^{2}$ HSCW-Hot summer and cold winter zone. ${ }^{3}$ HSWW-Hot summer and warm winter zone.

\subsection{Clothing Insulation}

The clothing has the insulating property which is a key factor for adjusting the heat loss and thermal comfort of human body. In this investigation, clothing insulation (clo) data were collected through questionnaires and estimated in the light of the standard ASHRAE 55.

The raw data in the scatter diagram was used to illustrate the relationship between the clo and indoor $t_{o p}$, as well as their linear regression results, as shown in Figure 9. In summer, most of the clo levels were concentrated in the range between 0.3 and 0.51 with the mean value of clo around 0.45 . In winter, most of the clo levels were from 0.83 to 1.31 with the mean value of 1.03. The clo level decreases in both summer and winter as the $t_{o p}$ increases.

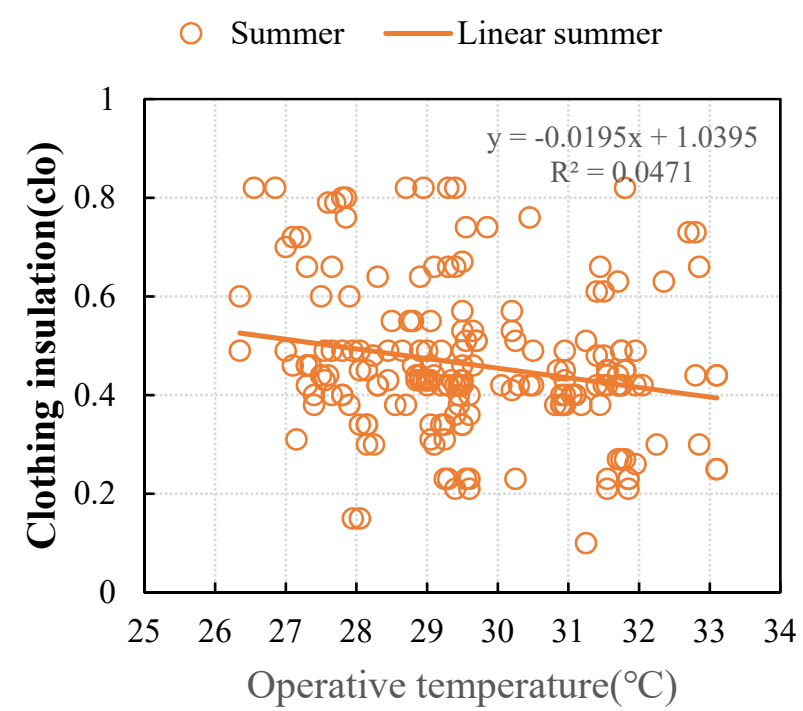

(a)

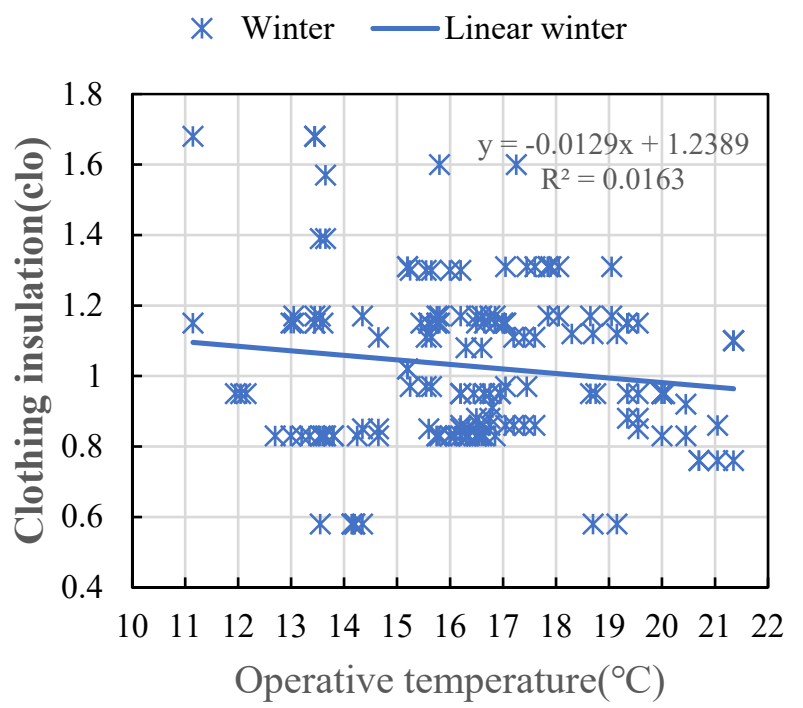

(b)

Figure 9. Relationship between clothing insulation and $\mathrm{T}_{\mathrm{op}}$. (a) Summer; (b) Winter. 


\section{Conclusions}

This paper analyses the data of a thermal comfort field study conducted in three types of naturally ventilated dwellings NF, NR, and NN in the Guilin karst area, China, during summer (61 days) and winter (42 days). The results are derived from environmental measurements, indoor and outdoor, taken in 144 dwellings and thermal comfort questionnaires collected for 414 responses of 223 participants, which could be extrapolated to karst areas in the hot summer and cold winter zone of China. The main conclusions are as follows:

1. In summer, an indoor thermal environment in dwelling NF was on average $1{ }^{\circ} \mathrm{C}$ cooler compared with that in dwelling NR and $0.5^{\circ} \mathrm{C}$ cooler than that in dwelling $\mathrm{NN}$. In winter, average indoor temperature in dwelling NR was $2.7^{\circ} \mathrm{C}$ warmer than that in dwelling NF and $1{ }^{\circ} \mathrm{C}$ warmer than that in dwelling NN. During both summer and winter, the fluctuations of indoor temperature and relative humidity in dwelling $\mathrm{NN}$ were the largest;

2. According to the TSVs, most occupants at about $81 \%$ were comfortable in winter, however, only $53 \%$ of the votes were comfortable in summer. The average TSV and PMV values were 1.42 and 1.60, respectively, in summer and -0.50 and -0.31 , respectively, in winter. The actual thermal comfort of occupants could not be precisely predicted by the classical PMV model, in most cases, as shown by the significant differences between TSV and PMV;

3. Although the most desired sensation was "neutral", the desired temperature was not always the thermal neutral temperature for occupants. As seen in the results of this study on thermal comfort, a negative relationship between thermal sensation votes and thermal preference votes suggested that occupants preferred warmness in the Guilin karst area of the HSCW zone during both summer and winter;

4. The range of actual accepted temperature $(80 \%)$ in summer and in winter was $20.9-27.5^{\circ} \mathrm{C}$ and $12.2-20.1{ }^{\circ} \mathrm{C}$, respectively. The actual thermal $\mathrm{T}_{\mathrm{n}}$ of $24.2^{\circ} \mathrm{C}$ and $16.2^{\circ} \mathrm{C}$ in summer and in winter, respectively, was lower than the predicted thermal $\mathrm{T}_{\mathrm{n}}$ of $25.7^{\circ} \mathrm{C}$ and $17.4{ }^{\circ} \mathrm{C}$ in summer and in winter, respectively.

Author Contributions: Conceptualization, X.G. and Q.M.; methodology, X.G. and Q.M.; software, Y.Y.; formal analysis, X.G.; investigation, X.G.; resources, Q.M.; data curation, X.G. and Y.Y.; writingoriginal draft preparation, X.G.; writing-review and editing, X.G.; supervision, Q.M. All authors have read and agreed to the published version of the manuscript.

Funding: This research was funded by the Natural Science Foundation of Guangxi Province, China (Grant No. 2020GXNSFBA297102); the project of the Foundation of State Key Laboratory of Subtropical Building Science, South China University of Technology (Grant No. 2021ZB05).

Institutional Review Board Statement: Not applicable.

Informed Consent Statement: Informed consent was obtained from all participation in the study.

Data Availability Statement: Not applicable.

Acknowledgments: The authors thank the subjects who volunteered for this survey. The authors thank J.C., L.H., C.C. and Z.W. for survey support.

Conflicts of Interest: The authors declare no conflict of interest.

\section{References}

1. Culic, A.; Nizetic, S.; Solic, P.; Perkovic, T.; Congradac, V. Smart monitoring technologies for personal thermal comfort: A review. J. Clean. Prod. 2021, 312, 127685. [CrossRef]

2. Tsinghua University Building Energy Research Centre (TUBERC). 2020 Annual Report on China Building Efficiency; Architecture and Building Press: Beijing, China, 2020. (In Chinese)

3. Kwong, Q.J.; Adam, N.M.; Sahari, B.B. Thermal comfort assessment and potential for energy efficiency enhancement in modern tropical buildings: A review. Energy Build. 2014, 68, 547-557. [CrossRef]

4. Liu, H.; Wu, Y.; Li, B.; Cheng, Y.; Yao, R. Seasonal variation of thermal sensations in residential buildings in the Hot Summer and Cold Winter zone of China. Energy Build. 2017, 140, 9-18. [CrossRef] 
5. Ozel, M. Effect of indoor design temperature on the heating and cooling transmission loads. J. Build. Eng. 2016, 7, 46-52. [CrossRef]

6. Fanger, P.O. Thermal Comfort: Analysis and Applications in Environmental Engineering; Danish Technical Press: Copenhagen, Denmark, 1970.

7. ISO. ISO 7730: Ergonomics of the Thermal Environment-Analytical Determination and Interpretation of Thermal Comfort Using Calculation of the PMV and PPD Indices and Local Thermal Comfort Criteria; International Standards Organization: Geneva, Switzerland, 2005.

8. ASHRAE Standards Committee. ANSI/ASHRAE55-2017, Thermal Environmental Conditions for Human Occupancy; American Society of Heating, Refrigerating and Air Conditioning Engineers, Inc.: Atlanta, GA, USA, 2017.

9. EN 16798-1:2019, Energy Performance of Buildings. Ventilation for Buildings. Indoor Environmental Input Parameters for Design and Assessment of Energy Performance of Buildings Addressing Indoor Air Quality, Thermal Environment, Lighting and Acoustics. 2019. Available online: https://shop.bsigroup.com/products/energy-performance-of-buildings-ventilationfor-buildings-indoor-environmental-input-parameters-for-design-and-assessment-of-energy-performance-of-buildingsaddressing-indoor-air-quality-thermal-environment-lighting-and-acoustics-module (accessed on 8 November 2021).

10. Rupp, R.F.; Vásquez, N.G.; Lamberts, R. A review of human thermal comfort in the built environment. Energy Build. 2015, 105, 178-205. [CrossRef]

11. Yao, R.; Liu, J.; Li, B. Occupants' adaptive responses and perception of thermal environment in naturally conditioned university classrooms. Appl. Energy 2010, 87, 1015-1022. [CrossRef]

12. Dear, R.D.; Brager, G.S. The adaptive model of thermal comfort and energy conservation in the built environment. Int. J. Biometeorol. 2001, 45, 100-108. [CrossRef]

13. Nicol, F.; Humphreys, M. Derivation of the adaptive equations for thermal comfort in free-running buildings in European standard EN15251. Build. Environ. 2010, 45, 11-17. [CrossRef]

14. Carlucci, S.; Bai, L.; Dear, R.D.; Yang, L. Review of Adaptive Thermal Comfort Models in Built Environmental Regulatory Documents. Build. Environ. 2018, 137, 73-89. [CrossRef]

15. Dear, R.D.; Xiong, J.; Kim, J.; Cao, B. A review of adaptive thermal comfort research since 1998. Energy Build. 2020, $214,1-10$. [CrossRef]

16. Karyono, K.; Abdullah, B.M.; Cotgrave, A.J.; Bras, A. The adaptive thermal comfort review from the 1920s, the present, and the future. Dev. Built Environ. 2020, 4, 100032. [CrossRef]

17. Xiong, Y.; Liu, J.; Kim, J. Understanding differences in thermal comfort between urban and rural residents in hot summer and cold winter climate. Build. Environ. 2019, 165, 106393. [CrossRef]

18. Cao, B.; Zhu, Y.; Ouyang, Q.; Zhou, X.; Huang, L. Field study of human thermal comfort and thermal adaptability during the summer and winter in Beijing. Energy Build. 2011, 43, 1051-1056. [CrossRef]

19. Wu, Z.; Li, N.; Wargocki, P.; Peng, J.; Li, J.; Cui, H. Adaptive thermal comfort in naturally ventilated dormitory buildings in Changsha, China. Energy Build. 2019, 186, 56-70. [CrossRef]

20. Manu, S.; Shukla, Y.; Rawal, R.; Thomas, E.L.; Dear, R.D. Field studies of thermal comfort across multiple climate zones for the subcontinent: India Model for Adaptive Comfort (IMAC). Build. Environ. 2016, 98, 55-70. [CrossRef]

21. Rupp, R.F.; Kim, J.; Ghisi, E.; Dear, R.D. Thermal sensitivity of occupants in different building typologies: The Griffiths Constant is a Variable. Energy Build. 2019, 200, 11-20. [CrossRef]

22. Maykot, J.K.; Rupp, R.F.; Ghisi, E. A field study about gender and thermal comfort temperatures in office buildings. Energy Build. 2018, 178, 254-264. [CrossRef]

23. Wang, Z.; Dear, R.D.; Luo, M.; Lin, B.; He, Y.; Ghahramani, A.; Zhu, Y. Individual difference in thermal comfort: A literature review. Build. Environ. 2018, 138, 181-193. [CrossRef]

24. Williams, P. Geomorphic inheritance and the development of tower karst. Earth Surf. Process. Landf. 1987, 12, 453-465. [CrossRef]

25. ISO. ISO 7726-1998, Ergonomics of the Thermal Environment-Instruments for Measuring Physical Quantities; International Standards Organization: Geneva, Switzerland, 1998.

26. Ministry of Housing and Urban-Rural Development of the People's Republic of China. GB/T 50785-2012, Evaluation Standard for Indoor Thermal Environment in Civil Buildings; Ministry of Housing and Urban-Rural Development of the People's Republic of China: Beijing, China, 2012. (In Chinese)

27. Ministry of Housing and Urban-Rural Development of the People's Republic of China. JGJ/T 347-2014, Standard of Test Methods for Thermal Environment of Building; Ministry of Housing and Urban-Rural Development of the People's Republic of China: Beijing, China, 2014. (In Chinese)

28. Brager, G.S.; Dear, R.D. Thermal adaption in the built environment: A literature review. Energy Build. 1998, 27, 83-96. [CrossRef]

29. Broday, E.E.; Ruivo, C.R.; da Silva, M.G. The use of Monte Carlo method to assess the uncertainty of thermal comfort indices PMV and PPD: Benefits of using a measuring set with an operative temperature probe. J. Build. Eng. 2021, 35, 101961. [CrossRef]

30. Ekici, C. Measurement uncertainty budget of the PMV thermal comfort equation. Int. J. Thermophys. 2016, 37, 48. [CrossRef]

31. Xing, D.; Li, N. Three-dimensional heat transfer of globe thermometers in indoor environments controlled by radiant systems. Build. Environ. 2021, 15, 107505. [CrossRef]

32. Peng, T.; Zhang, Y.; Jiang, X.; Yang, Y.; Fang, Z.; Zheng, Z. Investigation of pregnant women thermal comfort in the waiting area of the hospital in South China, Guangzhou. J. Build. Eng. 2021, 44, 103254. [CrossRef] 
33. Ficco, G.; Palella, B.I.; Riccio, G. On the measurement of the mean radiant temperature by means of globes: An experimental investigation under black enclosure conditions. Build. Environ. 2021, 193, 107655. [CrossRef]

34. Yang, J.; Nam, I.; Sohn, J.R. The influence of seasonal characteristics in elderly thermal comfort in Korea. Energy Build. 2016, 128, 583-591. [CrossRef]

35. Dhaka, S.; Mathur, J.; Brager, G.S.; Honnekeri, A. Assessment of thermal environmental conditions and quantification of thermal adaptation in naturally ventilated buildings in composite climate of India. Build. Environ. 2015, 86, 17-28. [CrossRef]

36. Jiao, Y.; Yu, H.; Yu, Y.; Wang, Z.; Wei, Q. Adaptive thermal comfort models for homes for older people in Shanghai, China. Energy Build. 2020, 215, 109918. [CrossRef]

37. Yao, R.; Li, B.; Liu, J. A theoretical adaptive model of thermal comfort-adaptive predicted mean vote (aPMV). Build. Environ. 2009, 44, 2089-2096. [CrossRef]

38. Jiao, Y.; Yu, H.; Wang, T.; An, Y.; Yu, Y. Thermal comfort and adaptation of the elderly in free-running environments in Shanghai, China. Build. Environ. 2017, 118, 259-272. [CrossRef]

39. Webb, C. An analysis of some observations of thermal comfort in an equatorial climate. Br. J. Ind. Med. 1959, 16, 297-310. [CrossRef]

40. Chen, X.; Gao, L.; Xue, P.; Du, J.; Liu, J. Investigation of outdoor thermal sensation and comfort evaluation methods in severe cold area. Sci. Total. Environ. 2020, 749, 141520. [CrossRef]

41. Shao, T.; Jin, H. A field investigation on the winter thermal comfort of residents in rural houses at different latitudes of northeast severe cold regions, China. J. Build. Eng. 2020, 32, 101476. [CrossRef]

42. Zhu, P.; Guo, F.; Zhu, T.; Liu, S. Field investigation of indoor thermal environment and thermal adaption of Dalian residences in winter. Appl. Mech. Mater. 2013, 361-363, 458-463. [CrossRef]

43. Xu, C.; Li, S.; Zhang, X.; Shao, S. Thermal comfort and thermal adaptive behaviours in traditional dwellings: A case study in Nanjing, China. Build. Environ. 2018, 142, 153-170. [CrossRef]

44. Yan, H.; Mao, Y.; Yang, L. Thermal adaptive models in the residential buildings in different climate zones of Eastern China. Energy Build. 2017, 141, 28-38. [CrossRef]

45. Li, B.; Yu, W.; Liu, M.; Li, N. Climatic strategies of indoor thermal environment for residential buildings in Yangtze River Region, China. Indoor Built Environ. 2011, 20, 101-111. [CrossRef]

46. Wu, Z.; Li, N.; Wargocki, P.; Peng, J.; Li, J.; Cui, H. Field study on thermal comfort and energy saving potential in 11 split air-conditioned office buildings in Changsha, China. Energy 2019, 182, 471-482. [CrossRef]

47. Zhang, Y.; Chen, H.; Wang, J.; Meng, Q. Thermal comfort of people in the hot and humid area of China-impacts of season, climate, and thermal history. Indoor Air 2016, 26, 820-830. [CrossRef]

48. Lu, S.; Pang, B.; Qi, Y.; Fang, K. Field study of thermal comfort in non-air-conditioned buildings in a tropical island climate. Appl. Ergon. 2018, 66, 89-97. [CrossRef] [PubMed]

49. Hwang, R.L.; Chen, C.P. Field study on behaviors and adaptation of elderly people and their thermal comfort requirements in residential environments. Indoor Air 2010, 20, 235-245. [CrossRef] [PubMed] 